Article

\title{
An Aesthetic Pattern of Nonbelonging-Immigration and Identity in Contemporary Israeli Art
}

\author{
Emma Gashinsky \\ Department of Arts, Ben-Gurion University of the Negev, P.O.B. 653, Beer-Sheva 8410501, Israel; \\ emmaga77@gmail.com
}

Received: 18 October 2019; Accepted: 12 November 2019; Published: 26 November 2019

check for updates

\begin{abstract}
This research pinpoints a local pattern of migratory aesthetics recurrently employed by four Israeli artists in the early years of the 21st century. I argue that works by artists Philip Rantzer, Gary Goldstein, Haim Maor, and David Wakstein showcase a hybrid migratory self-definition that is embedded in the artistic language itself. By harnessing a collagistic language of juxtaposition and fragmentation, they frame Israeli identity as uncanny, reflecting a cultural mindset of being neither "here" nor "there". I contend that this pattern is used by a particular generation of artists, born in the early 1950s, and reflects a reaction, in hindsight, to the Zionist ethos of collective local identity. Employing old photographs from their family albums that they transform into framed detached figures, these artists draw upon childhood memories of immigration. Their art marks an identity clash between two homelands, which is the result of intertwined aesthetic and socio-cultural characteristics. The first is evident in the prevalent use of collage in local art-in itself a language of oppositions. The second is the negation of the diaspora in the Israeli socio-cultural mentality, which constructs identity through binary thinking. To date, no other study has acknowledged this aesthetic pattern nor the common ground these artists share in their works.
\end{abstract}

Keywords: migration; immigration; Israeli art; identity stratification; negation of diaspora; historiography of art; holocaust representations; childhood memories; familial photograph albums; collage

\section{Introduction}

On the way to my first meeting with Israeli artist Philip Rantzer last spring, on a busy industrial street in South Tel Aviv, I noticed a small barred window at the entrance to his studio in which a stenciled sentence in Romanian sits above three miniature sculptures (Figure 1). The inscription reads: "O mică vitrine de Artă Contemporană" ("A Small Display Window of Contemporary Art"). If, despite of its small size, a passerby notices this inscription, the use of Romanian renders it unreadable to most, so it becomes a private comment in a foreign language. A form of self-presentation, this display subverts the norm, substituting the local language with an inaccessible one while ridiculing the practice of marketing art. Its irony is typical of Rantzer's idiosyncratic oeuvre, as is his recurring use of texts in Romanian and his preoccupation with notions of migratory versus local identity.

In recent decades, the art scene in Israel has witnessed a growing surge of works that address the notion of immigration and focus on personal narratives of diasporic origin. They provoke inquiry into the very definition of what it means to be Israeli in a society that still comprises mostly first-, second-, and third-generation immigrants. The manner in which various artists deal with this subject frequently triggers a sense of displacement, estrangement, and nonbelonging. The return to personal narratives, often resulting in the representation of a conflicted identity, captures the zeitgeist of Israeli 
culture from the 1980 s onward. ${ }^{1}$ This preoccupation with identity is due to intersecting internal and external factors, namely the absorption of international cultural discourses of identity-related issues and an acute local cultural crisis during the 1970s, which witnessed a growing divisiveness regarding the dominant Zionist paradigm of a national collective identity. Over the last two decades, artists have often addressed these concepts through images describing, or deriving from, their family photo albums. I contend that this intense, ongoing preoccupation with identity results, among a certain group of artists, in recurring visual patterns that have crystallized into a local manifestation of migratory aesthetics.

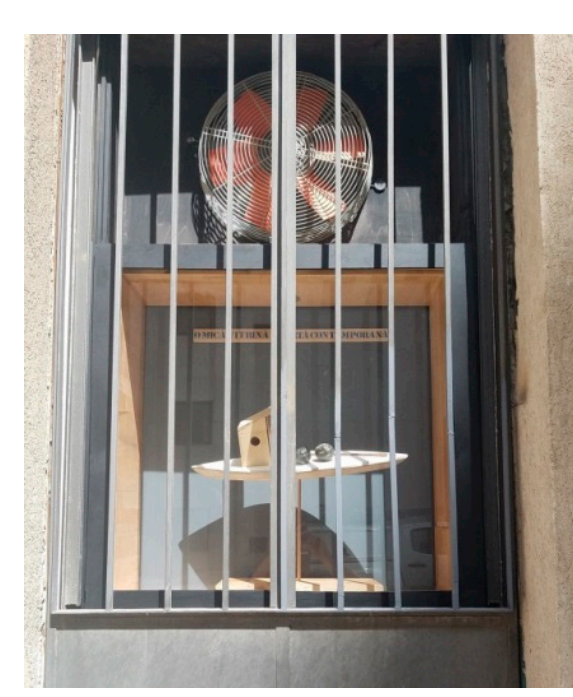

(a)
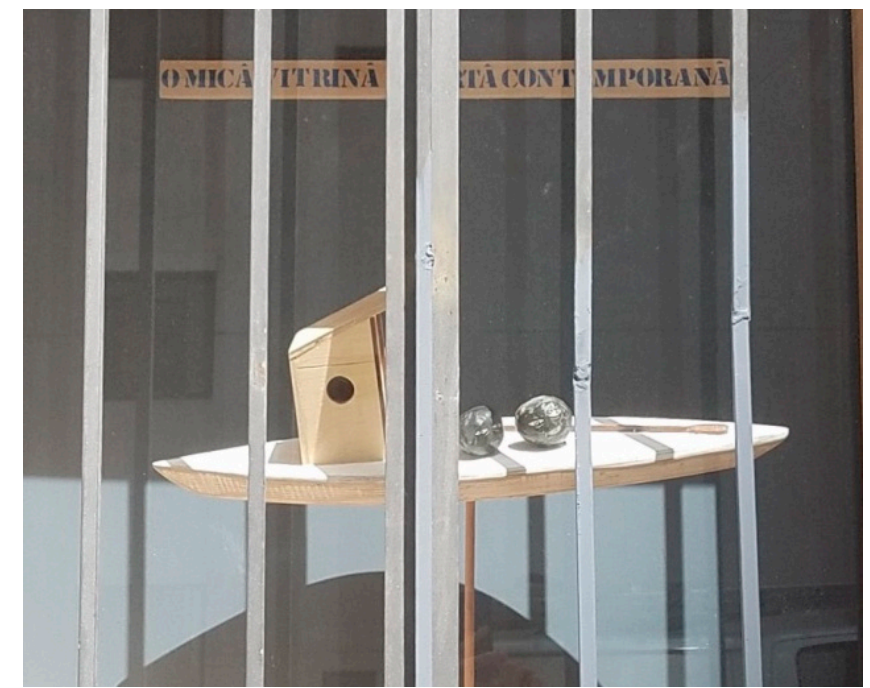

(b)

Figure 1. (a) A display window at the entrance to Philip Rantzer's Studio, South Tel Aviv, July 2019. Photograph; (b) enlarged for detail. photograph: Emma Gashinsky

David Wakstein, Gary Goldstein, Haim Maor, and Philip Rantzer were born between 1950 and 1956 to families originating from Eastern Europe. With the exception of Goldstein, who immigrated to Israel on his own in 1977, their parents or their own arrivals occurred between 1948 and 1960, in the context of the massive immigration wave to the new State of Israel. They are all established artists and teachers on the local art scene who launched their careers during the second half of the 1970s. They share an artistic language developed later in their careers that conveys personal narratives through recollections of childhood memories of migration. One particularly prominent aspect of their art is a self-articulation fluctuating between past and present homelands. The result is mostly a hybrid, conflicted identity dominated by a sense of displacement and dissimilation. Although they are all well acquainted as colleagues and have influenced each other in their mutual preoccupation with these memories, the fact that each has a highly individual style is probably the reason why the local art scene has overlooked their strong thematic affinities. More particularly, the visual pattern that I am attempting to define in this study had not yet been acknowledged in research.

The present study pinpoints a local pattern of migratory aesthetics that these four artists employed recurrently between 1999 and 2008. I argue that in these case studies, a migratory self-definition is embedded in the artistic language itself. By harnessing a collagistic language of fragmentation, Israeli identity is framed in their later works as uncanny and is delineated as a cultural state of mind of being

1 Artistic preoccupation with migration and diaspora has always been present in local Israeli art, although it was consistently marginalized in the past. Former representations of migration differ significantly from contemporary ones in their use of symbolic language, as exemplified by the works of artists Naftali Bezem (Germany 1924-Israel 2018) and Yosl Bergner (Austria 1920-Israel 2017). 
neither "here" nor "there". I contend that this particular pattern marks an identity rift between two homelands and is the result of local, intertwined aesthetic and socio-cultural characteristics. The first is the prevalent local use of collage-in itself a language of oppositions. The second is the negation of the diaspora in the Israeli socio-cultural habitus, ${ }^{2}$ one of constructing identity through binary thinking.

\subsection{Methodology and Theoretical Framework}

This study has two central parts. First, I characterize a particular aesthetic pattern that conveys migration and dissimilation as its frame of reference by analyzing four representative works. This part includes an analysis of the local historiography of art during the 1970s, which I see as the origin of this aesthetic. By doing so, I hope to emphasize the uniqueness of local migration aesthetics. Furthermore, by introducing a precedent in an artwork by Moshe Gershuni (1936-2017) as my point of departure, I contextualize the discussion by basing it on the enduring centrality of the negation of the diaspora in the local mentality. The second part focuses on a close exploration of the messages that these artists convey in their works and their common approach regarding form, meaning, and autobiography. I draw upon primary data garnered in extensive interviews that I conducted with the four artists. Recent scholarship in Israel studies and Zionism provides a context for the methods of analysis from the fields of art history and historiography of art, while also relating to migratory aesthetic theories developed primarily over the last decade. ${ }^{3}$

I show how these artists reflect the "mobility turn". Emerging in the social sciences during the 1990s, this concept's principal contention is the refutation of the dichotomy of what is perceived as "normal" locational stability versus migration and instability. ${ }^{4}$ In direct relation to the mobility turn, scholars broadly define migratory aesthetics as various artistic strategies conveying mobility, movement, and displacement. ${ }^{5}$ Especially related to the pattern introduced in my research is the visual conceptualization of migratory identity, as Sam Durrant and Catherine M. Lord put it, of "being caught, even frozen, in transition, between lives and countries [ ... ] not so much subjects-in-process as subjects-on-hold, subjects-in-stasis" (Durrant and Lord 2007b, p. 12). From a different angle, recent scholarship on diaspora and migration concentrates on the tense relationship between immigrant cultures and the indigenous culture in the country where the immigrant settles (De Souza 2011, p. 362; Durrant and Lord 2007b, pp. 11-20). In the particular case of modern Israeli culture, in which many are basically newcomers, this scheme seems more complex. This complexity arises from the hegemonic Zionist-based model of a new local identity and its evolution over the last century. It is based on the negative, stereotypical perception of the diasporic Eastern European ("Ashkenazi") Jew, while excluding the population's diverse cultures of origin.

Recent research on Israeli art and migration focuses primarily on ethnic and gender groups whose cultural underrepresentation demonstrates this cultural marginalization. ${ }^{6}$ Several studies have highlighted the notion of nonbelonging in relation to immigration, mostly in case studies of younger contemporary artists. ${ }^{7}$ More generally, a recent article by Yael Guilat examines cultural belonging by applying the terms "inside" and "outside agency" to contemporary "local home images" (Guilat

\footnotetext{
Bourdieu defines habitus as "a set of dispositions that incline agents to act and react in certain ways" (Bourdieu 1991, p. 12). Three central references on migration and aesthetics are (Petersen 2017; Mathur 2011; Durrant and Lord 2007a).

On the mobility turn, see (Urry 2007). For a contextualization of this term into current migratory aesthetic discourse, see (Petersen 2017, pp. 1-46).

5 See, for example, (Bal 2007; Durrant and Lord 2007b, pp. 23-36; Mitchel 2011; and Mathur 2011, pp. 59-77).

6 This includes 'Mizrahi' Israelis (a local term for immigrants from the Middle East and North Africa). In 1998 the Israel Museum held the first major exhibition focusing on Eastern influences on local art (Zalmona and Manor-Friedman 1998). Israeli Mizrahi identity has gradually become a significant artistic subject during the last two decades, see (Maor 2014a). For research on the art and identity of women who emigrated from the former Soviet Union and Ethiopia in the early 1990s, see (Dekel 2016; Dekel et al. 2017). On artistic explorations of identity stratification among local Palestinian, Arab-Israeli, Bedouin, and Druze and their intricate state of imposed migration, see (Makhoul and Hon 2013; Ankori 2006).

7 See, for example, (Barkai 2016). Barkai focuses on Israeli-born artists from a younger generation who live and work outside of the country, and thus on the impact of their decision to emigrate on their self-articulation, which results in a state of mind of being in-between.
} 
2019a). A small number of local exhibitions during the last decade have focused on representations of childhood memories and photographs that the respective artists took from their family albums, frequently (but not exclusively) addressing immigration and uprooting. ${ }^{8}$ From a different angle, in her exhibition catalog Routes of Wandering (the Israel Museum, 1991), Sarit Shapira was the first to detect the centrality of migration in local art as well as the idea of wandering as inherent to a Jewish frame of mind and its significance in shaping Israeli self-articulation (Shapira 1991).

Researchers have yet to explore the field of Israeli art sufficiently, especially regarding the generation of artists who launched their careers during the late 1970s and early 1980s. Yael Guilat's book The "Lost" Generation: Young Artists in 1980s Israeli Art (Guilat 2019b) highlights immigration as a central theme of that decade. ${ }^{9}$ Although this is an essential contribution, it addresses the work of these artists during a particular timespan-the 1980s. Study of Wakstein, Maor, Goldstein, and Rantzer's more recent work is mostly confined to short texts in catalogs for their solo exhibitions.

\subsection{Defining a Local Migratory Pattern and Its Context in the Historiography of Israeli Art}

A selection of four artworks by Goldstein, Wakstein, Maor, and Ranzer serves to demonstrate this visual pattern (Figures 2-5). They all share three prominent visual elements. The primary feature is the representation of framed figures, mostly faces, applied on a collagistic language of juxtaposition. Shaped by the right angles of these individual frames, this collagistic aesthetic is closely related to a loose grid structure, an emblematic feature of modernism that divides the picture plane into segments. Second is the use of a restricted color palette, mostly of monochromatic beige or light wood-brown (sometimes as a result of uncolored cardboard, plywood, or wood). The third feature is a frequent use of text in various languages. These features can be redefined in terms of migratory aesthetics. Detached faces are confined within discernible framed squares and rectangles, detached from their background and from each other. The separation of the figures from the background visually translates a sense of displacement into form. Undermining unity and clarity, compartmentalization of the figures creates a sense of dislocation. The use of a limited palette—at times drained of color-paired with disoriented photographs or portraits results in a visual language that, in Roland Barthes's terminology, becomes a signifier of the past tense (Barthes 1981). Barthes referred to the paradox of photographs as a medium that transfixes a split second in time and is perceived as a "natural witness of what has been", thus creating an "image which produces Death while trying to preserve life" (ibid., pp. 92-93).

8 A 2019 exhibition at the Artists' House in Tel Aviv, the show And the Ship Still Sails (curator: Dalia Danon) focused on found personal objects as agencies of childhood memory and diasporic origin. The exhibition Souvenirs, which Haim Finkelstein and Haim Maor co-curated (May-August 2008, The Senate Gallery, Ben-Gurion University of the Negev), explored repressed historical and personal memories in works by Israeli and Polish artists. The 2009 exhibition Family Traces at the Israel Museum (curator: Tamar Manor-Friedman) explored family photo albums, with a section referring to the work of Israeli artists, which notably served as "testimony to a history of displacement and loss." Exhibition site, The Israel Museum, https://museum.imj.org.il/exhibitions/2009/FamilyTraces/about.html. Retrieved: 5 April 2019.

9 Ibid., see especially pp. 113-114, 203-205. 


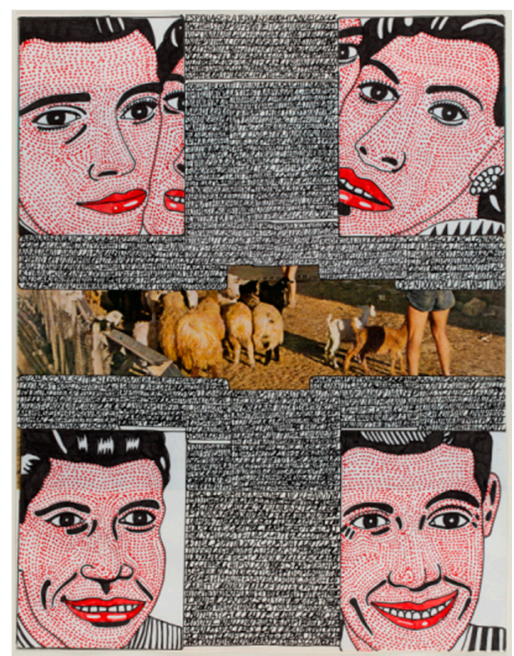

Figure 2. Gary Goldstein, from the series Israel's First Decade, 2005, mixed media on paper, $29 \mathrm{~cm} \times 22$ $\mathrm{cm}$, The Levin Collection, Jerusalem. Image courtesy of Levin Art, Community \& Culture.

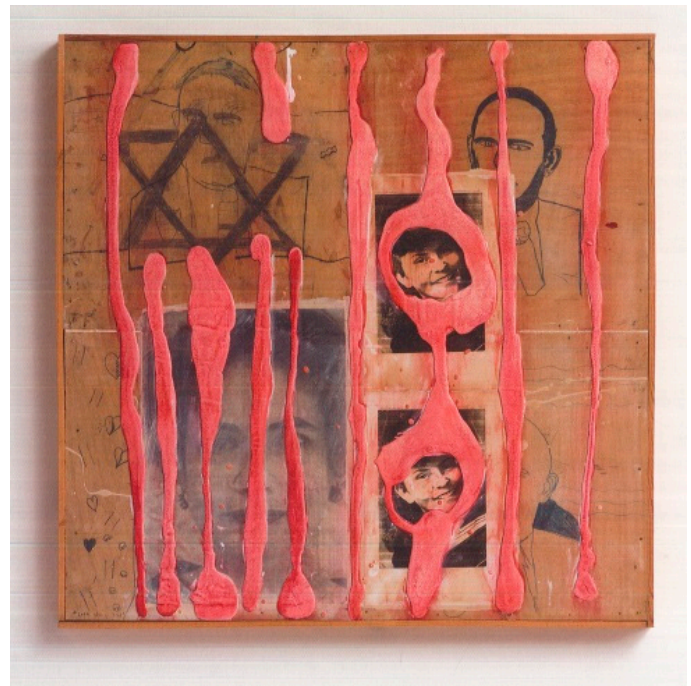

Figure 3. David Wakstein, Sonia, 2006, mixed media on plywood $81.5 \mathrm{~cm} \times 81.5 \mathrm{~cm}$. Image courtesy of the artist.
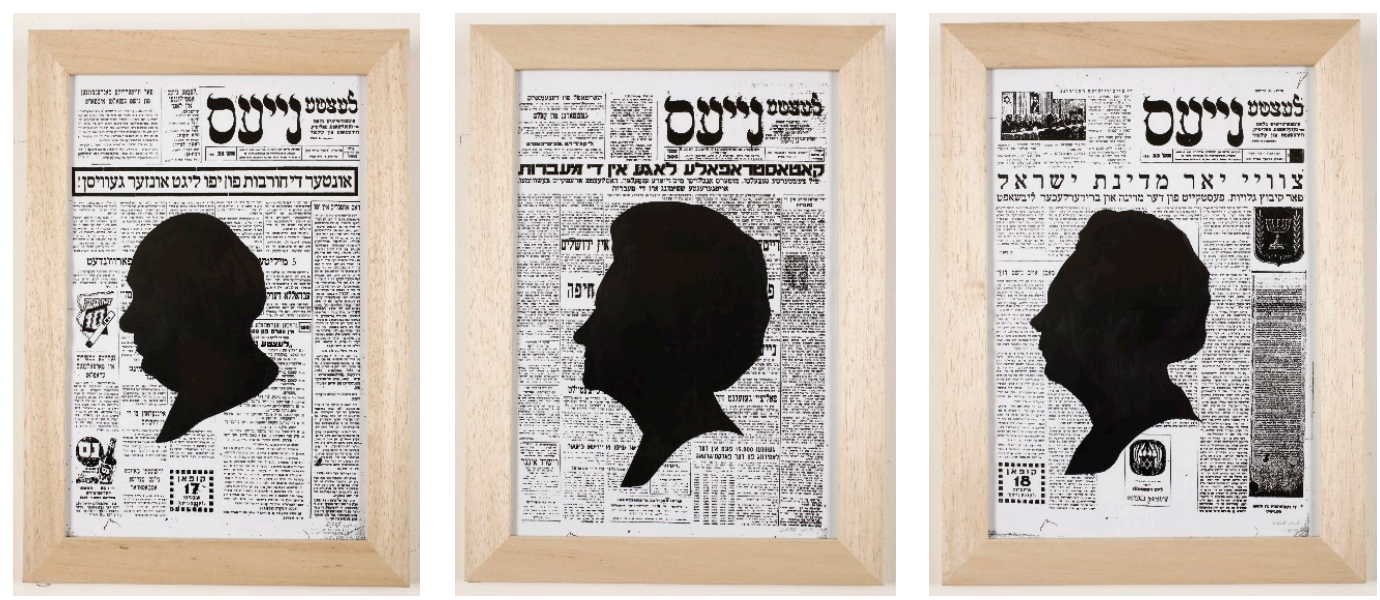

Figure 4. Haim Maor, Self-Portrait with My Parents (Letste Nayes), triptych, 2008, acrylic on digital print, $40 \mathrm{~cm} \times 29 \mathrm{~cm}$ each, $40 \mathrm{~cm} \times 87 \mathrm{~cm}$ total, collection of the artist. Images courtesy of the artist. 


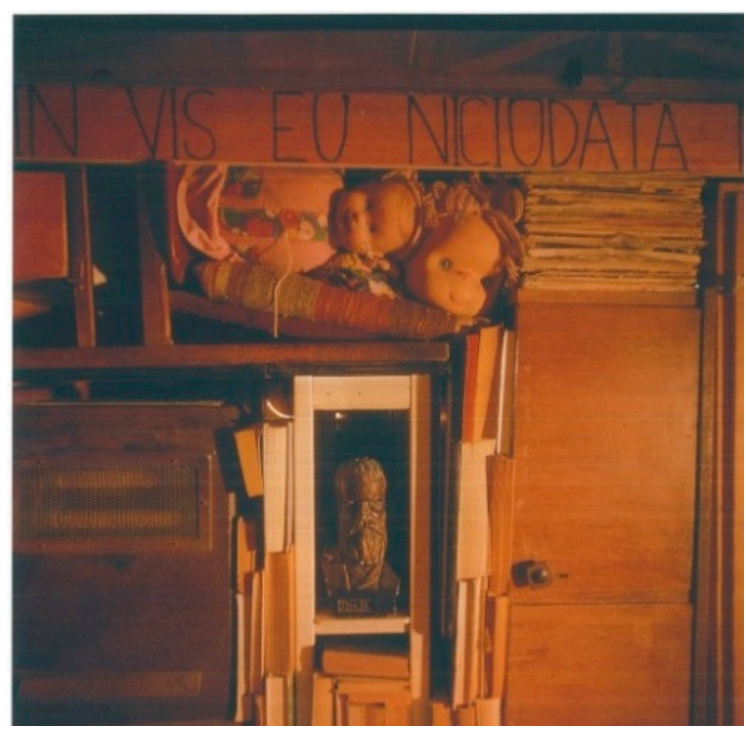

Figure 5. Philip Rantzer, Untitled, 1999. Details from an installation at the Venice Biennale, 1999. Photograph: Philip Rantzer. Image courtesy of the artist.

As both a medium and an aesthetic, collage is a striking representative of modernistic formalism, and a dialectical confrontation between its components lies at the core of its language. In his well-known essay Collage (1959), prominent modernist critic Clement Greenberg ascribed the unique quality of collage on a formalistic level as "an oscillation between surface and depth", which constitutes a relationship of contrast, and as a "detachment and isolation of plasticity" (Greenberg 1959, pp. 77-78). With the departure from the formalism of modernism, such a pattern of confronting oppositions has proven an appropriate technique in conceptual and postconceptual art for conveying conflicting notions. Israeli curator Irith Hadar has addressed its use in portraying social-cultural identity:

Collage-in denying semblances of order and purist wholeness, in its hybridism and artificialness, in its confronting pieces of reality with fiction, what we know with what we see-presents reality as a simultaneous existence, reciprocal in the affinities of complementary and conflicting powers. Meaning and identity are constituted within it through the examination of their mutual relationships. In this sense-and in the cultural-social context-the very collagist construction may be a statement. (Hadar 2009, p. 174)

Juxtaposition of photographs and texts and the prevailing use of monochromatic beige or wood-brown are rightfully framed within the local historiography of art as part of the artistic development of the 1960s and 1970s. ${ }^{10}$ Whereas these features owe a debt to international influences, they are also the essence of what is identified as a local style, largely defined as a specific blend of lyrical abstract, material "poverty" or meagerness, and collagism (Ofrat 1998, p. 322; Shehori 1974, pp. 30-31). ${ }^{11}$ This aesthetic inclination was interpreted by local critics and curators as primarily formalistic, under the prevailing dominance of modernistic criticism, which persisted on the Israeli art scene until well into the 1970s. A highly influential, canonic text, which Sarah Breitberg-Semel, the curator of the Tel Aviv Museum, published in 1986, granted this local style its prominent position within local historiography. Accompanying the exhibition The Want of Matter: A Quality in Israeli Art, this text was an ambitious attempt to define a local aesthetic sensitivity. Breitberg-Semel claimed that there is an "inner code" in the local art of the 1970s that distinguishes it from American or European art: a meager,

10 On the dominance of collage as a central feature of local art during the 1960s and the 1970s, and the inclusion of texts within it, see (Fischer and Manor-Fridman 2008, pp. 49-53).

11 Two additional directions in local art during the 1970s were conceptual art absorbed in epistemological interrogations and political actions and performances. See (Ofrat 1980, pp. 277-327). 
poor aesthetic quality, devoid of the sensual richness of Western culture. In addition to "meagerness", two key words that she frequently repeated in her text are "collage" and "confrontation". ${ }^{12}$ Indeed, the frequent application of a collage to a meager surface, mostly cardboard, characterizes this localism. Maor, Wakstein, and Rantzer studied in major local art institutions during the 1970s and were taught by artists such as Raffi Lavie (1937-2007) and Moshe Gershuni, who were leading representatives of this prevailing style. ${ }^{13}$

Whereas the local historiographic background establishes the prevalence of this particular visual language as quintessentially Israeli, ironically its contemporary manifestations, as can be seen in Figures 2-5, attenuate its original use in two fundamental respects. First, the anchor for these works lies in personal narratives of immigration, a thematic orientation that represents a rebellion against the rejection of content by the local canon of the 1970s. As Philip Rantzer recalls: "When I was a student, the slogan was that art shouldn't be literal. This is as literal as you can get"14 (Figure 5). Second, by using this strikingly local style to portray detachment and dissimilation, these works undermine the sense of cultural belonging. Yet, the artists created these works two or three decades after this phase in Israeli art, presenting a later revision rather than continuity. Before reclaiming this "meager" style, representatives of the new generation departed dramatically from their teachers' aesthetics. Art historian Gideon Ofrat referred to the 1980s as the period in which members of the generation of artists maturing in the early 1980s were "free' of the umbilical cord of the local avant-garde (lyrical abstract, material 'poverty', and collagism)" (Ofrat 1998, p. 322). Under the heavy influence of neo-expressionism - prevalent in the international art scene of that time- these young artists revived figuration and an expressive personal mode of representation (Guilat 2019b, pp. 112-119). By the 1990s, however, I argue that they found their way back to this dominant Israeli influence, albeit from a totally different viewpoint, reclaiming it by adapting it to their needs. In response to my question regarding his application of collagistic aesthetics in his works, Gary Goldstein said:

I think that during the 1990s, things gradually started to change. Artists began using collages as a means of talking about personal experiences, that is, not to make them universal but to let them operate as a particular narrative. ${ }^{15}$

It is important to note that, in addition to its full employment in the works of the four artists already mentioned, other local artists from the same generation also utilize this particular migratory pattern in their current work. Meir Pichhadze (Georgia 1955-Israel 2010) populated his canvases with portraits of his family members based on childhood photographs and created a bleak atmosphere of estrangement between the figures and a disorienting background. Talia Tokatly (born in Israel, 1949) and Shuka Glotman (born in Israel, 1953) used old family photographs in recent works, with an emphasis on their framing and detachment. Meanwhile, since the 1990s, Jack Jano (born 1950 in Morocco) has been creating juxtapositions of stability and mobility in his installations, which refer to a diasporic Jewish mindset of wandering. The compositions of Jenifer Bar-lev (born in Washington D.C., 1948) are made up of framed areas divided into further subsections, resulting in an intricate web of windows, borders, and compartments in which she represents conflicting notions of Israeli and Jewish identity, which do not necessarily overlap. A different take on this pattern appears in the works of Druze-Israeli artist Asad Azi (born in Israel, 1955), which depict his self-portrait and the

12 The word "collage" appears 19 times in her relatively short catalog essay (Breitberg-Semel 1986). This matter demands further consideration, but that lies beyond the limits of this research.

13 Wakstein studied in the Bezalel school of art, Jerusalem (1975-1979), whereas Maor and Rantzer studied at the Midrasha (Arts Teachers' Training College, Ramat Hasharon) (1973-1976, 1979-1982, respectively).

14 (Edelsztein 1993, p. 55). Similarly, Haim Maor recalled Raffi Lavie's negative reaction to his first show, which dealt with Jewish and identity-related content through the biblical story of Cain - an unequivocally repudiated subject in the art scene at that time- -dismissing his potential for becoming an accepted artist. In a similar vein, Lavie told Gary Goldstein that he would never be successful in becoming Israeli and would always be an outsider, meaning that as an insult. From conversations with the artists, April-June 2019.

15 From a conversation with the artist, March 2019. 
portrait of his father taken from the family album in a state of irreconcilable fragmentation, attesting to the exceptional complexity of being an Arab-Israeli Druze. ${ }^{16}$ We can assume that these works are the combined result of mutual local influences among peers indirectly influenced by the prevalent local art of the 1970s and conceptual international influences that developed during the 1980s into postconceptual representations of identity politics.

At this point, two social observations come to the fore. The first is that this pattern is used by artists from the same generation. As delineated above, I suggest that this is the result of the inner dynamics of the art field, with the 1950s generation reacting ambivalently toward their teachers and toward what is identified as local. In the following, I show how this scenario especially fits the identity rift that dominated the first decade of the State of Israel. The second observation is that, whereas its partial utilization appears in works by artists originating from diverse origins (Mizrahi, Ashkenazi, Arab-Druze), only male artists of Ashkenazi origin employ this pattern fully. As the complex social, cultural, and historiographical reasons for this demand a broader theoretical framework, which exceeds the scope of the present text, it will suffice for now simply to acknowledge it.

\subsection{Moshe Gershuni as a Precedent and the Negation of Diaspora}

Moshe Gershuni was a notable representative of canonic Israeli art, highly influential as both an artist and a teacher. One of his works, exhibited in the avant-garde Yodfat Gallery in Tel Aviv in 1974 (Figure 6), is a striking precedent for the use of the visual pattern in question. Either serving as the root for a local genealogy of migratory aesthetics or merely providing an early example, Gershuni bluntly defied the rejection of narrative, which characterized the local art field of his time, by harnessing local "meager" aesthetics to deal with his family's narrative of immigration. An inscription placed under three photographs identifies them as portraying the artist's father: "My father, Zvi Gershuni, immigrated to Palestine in 1929. He learned agriculture in France. He cultivated citrus groves and vineyards". The binary dualism formed by the juxtaposition of the prototypes represented in these photographs is an effective visual translation of the rift caused within Israeli society by the negation of diaspora. Understanding the wider context behind this conflicted local mentality requires a brief look at the construction of Jewish-Israeli culture in both Zionist thought and hegemonic nation building.

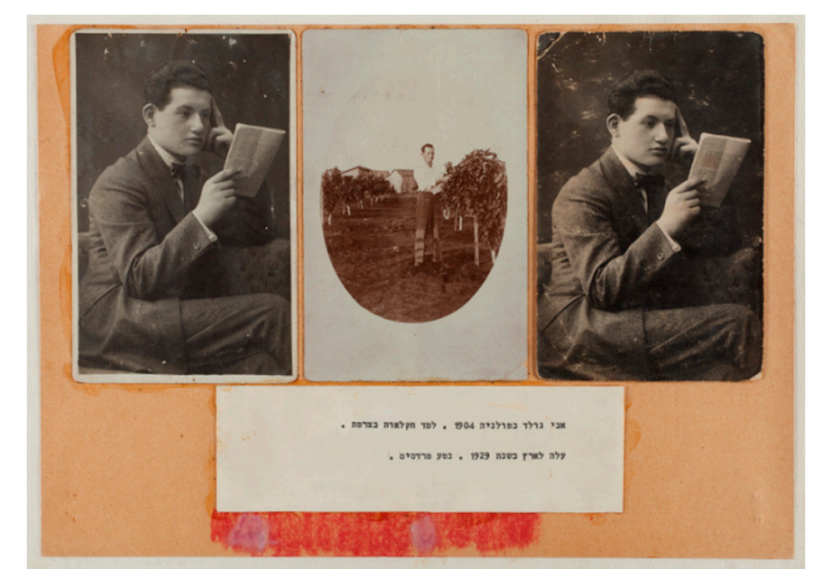

Figure 6. Moshe Gershuni, "My Father ... ", 1974, mixed media on paper, $21 \mathrm{~cm} \times 29.5 \mathrm{~cm}$, The Levin Collection, Jerusalem. Image courtesy of Levin Art Community \& Culture.

In applying the notion of migratory identity to the particularity of local socio-historical circumstances, it is worth noting two central features. First, the accepted "norm", which is still the notion of national, stable self-determination, is rather challenging within the context of Israel

16 For a detailed account of this complexity, see (Ankori 2006, pp. 178-196). 
as an immigrant state ${ }^{17}$. Second, with its roots in European Zionist ideology, this new model of identity-locally designated "Hebrew" and later "Sabra" rather than "Jewish"—-was dominated by the negation of diaspora and the centrality of the Land of Israel (Raz-Krakotzkin 2017). Jewish newcomers perceived the Land of Israel as their renewed homeland, a perception owed to the biblical promise of the land, which served as an infrastructure for the creation of a collective identity that denies its traditional exilic-diasporic roots. As Moshe Zuckermann noted:

Zionism was constituted ex negativo, relying on the two postulates "negation of Diaspora" and the birth of the "new Jew". This is why everything Jewish, reminiscent of "Diaspora", was pejoratively perceived and fought to be erased. ${ }^{18}$ (Zuckermann 2015)

The "melting pot" policy, a dominant national strategy that the State employed during the first years of its existence in order to cope with the mass immigration between 1948 and 1951, institutionalized and reinforced this stance. Driven by the perception that cultural diversity poses a threat to the construction of a collective identity, this policy was designed to unite immigrants from all over the world under a new cohesive national identity. In Anita Shapira's words, this meant:

[... ] bringing all the Jewish Diaspora under one cultural roof and having them all adopt the principle of progress, a nonreligious national worldview, and Hebrew language and culture.

All Jews from the Diasporas were called upon to shed the characteristics of their former culture and unite under the banner of the state and its symbols. ${ }^{19}$ (Shapira 2012, p. 393)

The local socio-cultural mentality of negating former cultural identities clashes with the fact that many Israelis have only arrived in the country relatively recently. Despite significant cultural changes in the postmodern mindset, which undermines the belief in national ideology—sometimes locally termed post-Zionism - the formative Zionist ethos of a new monolithic Israeli identity still prevails. Although the change in global cultural discourse in recent decades has significantly influenced local mentality with regard to acknowledging differences and accepting diversity, the fact that Israeli history is so young acts as a counterbalance.

Whereas Gershuni's collage clearly demonstrates the transformation from an originally diasporic identity to a Hebrew one, the visual means he used suggest that the result is an unreconciled double identity. His father's appearance in the identical photographs placed on the right and on the left, dressed in a European suit and reading, is in keeping with the iconographic pattern customary in the genre of portraiture of an educated man. This prototype is juxtaposed with the central image in which he is picking oranges in a grove in Palestine. Vita activa (an active life) replaced vita contemplativa (a contemplative life). In another version of this work, two omissions further accentuate the troubling confrontation between these identity models (Figure 7). In addition to removing one of the identical photographs, the caption now lacks the sentence: "He learned agriculture in France". This identity transformation attests to striking roots in the land while eliminating one's former identity, as viewers may conclude from the altered inscription, which now refers exclusively to his father's new identity. Concurrently, this transition is reflected in the blood-red paint that the artist smeared with his finger in the gap between the images and the text, as if he were signing a pact of blood with the land (Ofrat 2013, p. 377).

\footnotetext{
17 For a detailed discussion on the internal and external circumstances of immigration to Israel and their complex social and demographic implications, see (Goldscheider 2016).

18 Quoted from English abstract, for more, see (ibid., pp. 232-239).

19 For more on this subject, see (ibid., pp. 222-270).
} 


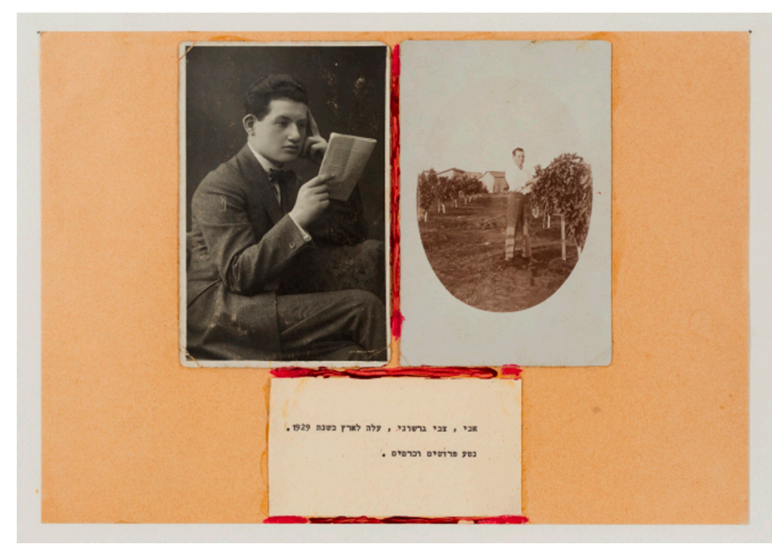

Figure 7. Moshe Gershuni, "My Father ... ", 1974, mixed media on paper, $20.8 \mathrm{~cm} \times 29.5 \mathrm{~cm}$. The Levin Collection, Jerusalem. Image courtesy of Levin Art Community \& Culture.

The use of a conceptual language, made up of the juxtaposition of photographs and texts, helps conceal the thematic personal narrative of migration that is at the very hub of this work. In curator Sara Breitberg-Semel's words, referring four decades later to Gershuni's early work from the 1970s: "Gershuni, at his most avant-garde, was already using the language of avant-garde to articulate a contrary notion and oppose the modernist dictate of the surface-a dictate to eradicate depth and interiority [ ... ]" (Breitberg-Semel 2011a, p. 12). At the time, local critics and curators ignored his "use of the language of avant-garde in order to invert it" (ibid.), focusing on the daring novelty of his artistic application of generic ready-made materials such as old family photographs (Breitberg-Semel $2011 b$, p. 52). This has only become clear in retrospect, in face of the total transformation of his artistic language at the turn of the 1980s into a neo-expressionistic style overtly focused on identity politics. ${ }^{20}$ Gershuni's subversive application of identity stratification to the acceptable language became an influential precedent for the emerging generation of new artists, even if it only came to fruition two decades later.

\subsection{David Wakstein-Sonia, Salma, and the Shoemaker}

In 1974, the same year in which Gershuni exhibited his collage, David Wakstein became one of his students at the Bezalel Academy of Arts, Jerusalem. His teacher's influence is unquestionable, as Wakstein has dealt with his own conflicted sense of identity throughout his career. Although, like Gershuni, he was born in Israel after his parents' immigration, Wakstein proclaims himself an immigrant, an identification that reflects his challenging childhood experiences. ${ }^{21}$ His Polish-born parents arrived in Israel in 1948, six years before his birth. When he was six years old, the family moved to the Bronx, New York; his mother's sudden death there led to a return to Israel a year later, this time to a kibbutz. Despite the appearance of his parents in a few works that he created during the 1980s and the 1990s, Wakstein only alluded to them directly later in his career, between 2004 and 2006. In Two Shoemakers (Figure 8) he refers to the fact that his father was a shoemaker as a signifier of a stereotype of the diasporic Jew.

20 Gershuni's focus on identity stratification during the early 1980s also largely addressed his homosexuality and confronted the ethos of Israeli masculinity by homoerotic references to soldiers. See, for example, (Zalmona 2013, pp. 323-27).

21 All information, unless specified otherwise, is taken from my conversations with the artist, May-July 2019. 


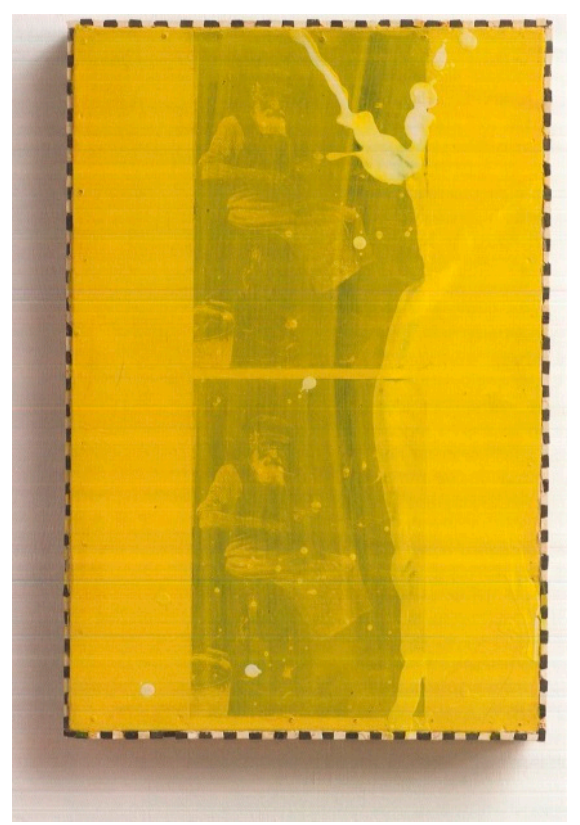

Figure 8. David Wakstein, Two Shoemakers, 2004, mixed media on plywood, $61.5 \mathrm{~cm} \times 41.5 \mathrm{~cm}$. Image courtesy of the artist.

Wakstein pasted two photocopies of an old black and white photograph of a shoemaker onto a plywood surface and covered them with a semi-transparent coat of yellow. The original image, a photograph of a Jewish cobbler in Poland between the two world wars (Figure 9), was appropriated from a book called Yiddishland (1999), ${ }^{22}$ a collection of postcards capturing Jewish life and Yiddish culture in Eastern Europe during the early 20th century. Wakstein found the volume in a second-hand bookstore in Tel Aviv and has used other images from it in his works over the last two decades, describing it as an ongoing fascinating source of inspiration. This album serves the artist as an alternative gateway to representations of the forsaken homeland of Poland and the memory of his Yiddish-speaking childhood home. In an interview with curator Yaniv Shapira five years ago, Wakstein recalled his childhood experience of arriving in Kibbutz Einat:

As I was adapting to this particular social sensitivity, I felt that my father wasn't part of the kibbutz's "clique". He was a simple shoemaker, perceived as a diasporic outsider. His work accentuated his foreignness in the social humanscape of the kibbutz. I was ashamed in him for not being a tractor or jeep driver, or planting cotton..$^{23}$

Clearly, Wakstein's experience of failed assimilation and cultural clashes was especially strong on a kibbutz during the 1960s. The discrepancy lying at the core of the estrangement, which this work conveys, derives not only from the screened double image, but also from the decision to frame the canvas with local mosaic stones. This unusual frame alludes both to the concrete aspects of the new homeland and to its ancient cultural history in stark contrast to the diasporic cobbler. It is an intimate work, conveying an irreconcilable identity in which the diasporic parental presence thwarts his attempts to fit in.

22 See (Silvain and Minczeles 1999), pages of photographs unnumbered.

23 Wakstein, 2014, interviewed by Yaniv Shapira (2014, p. 201). 


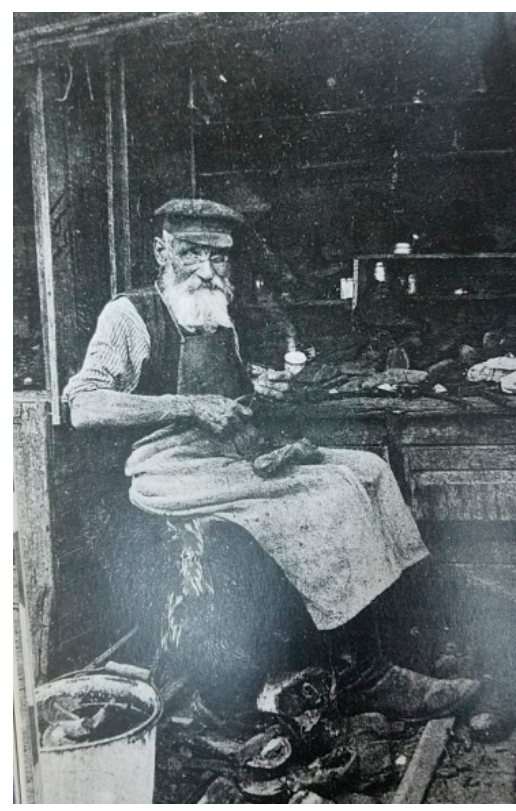

Figure 9. A postcard of a cobbler from the book Yiddishland, found in Wakstein's studio, photograph: Emma Gashinsky.

In a series of works created two years later, Wakstein replaced the stereotypical representation of the diasporic East European Jew with a photograph of his mother, Sonia, using her surname as the title (2006, Figures 3 and 10-13). A photograph of her taken in the early 1950s, which still hangs on the wall in the artist's studio (Figure 11), serves as the main feature, appearing two or three times in each work. The division of the plywood surfaces in this series into four sections forms a loose grid that is further divided by the frame of the recurring photographs. He applied thick paint directly over parts of the photographs, creating additional divisions in the composition in the form of loose strips reminiscent of a grating or a circle silhouetting one of the photographs. As in the image of the cobbler, the central artistic strategy is framing, thus denying the figure's hold on the background. Above all, these works convey a sense of emotional aggression that the expressive treatment of the impasto over and around the mother's image generates. In some places, Wakstein has circled, barred, or completely covered up his mother's face, perhaps as both a metaphor of the elusive nature of memory and a reflective negotiation of the possibility of representation.

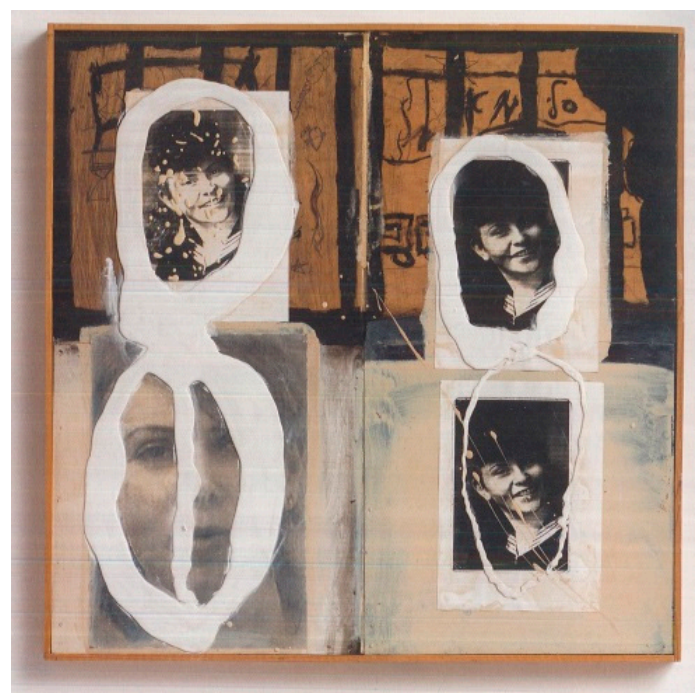

Figure 10. David Wakstein, Sonia, 2006, mixed media on plywood, $81.5 \mathrm{~cm} \times 81.5 \mathrm{~cm}$. Image courtesy of the artist. 


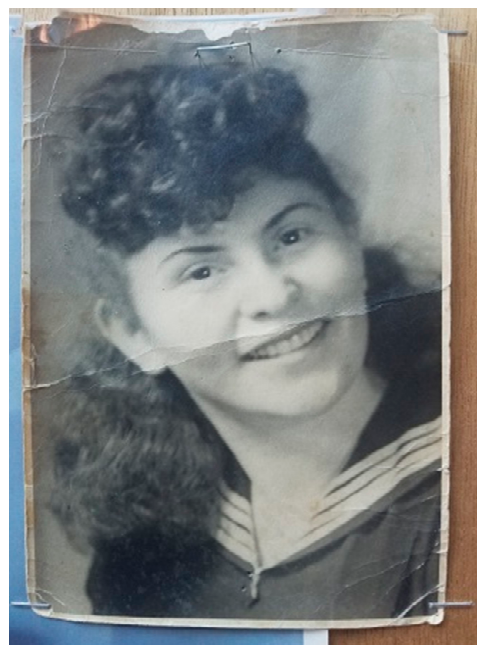

Figure 11. Photograph of Sonia Wakstein in Wakstein's studio, photograph: Emma Gashinsky. Image used by permission.

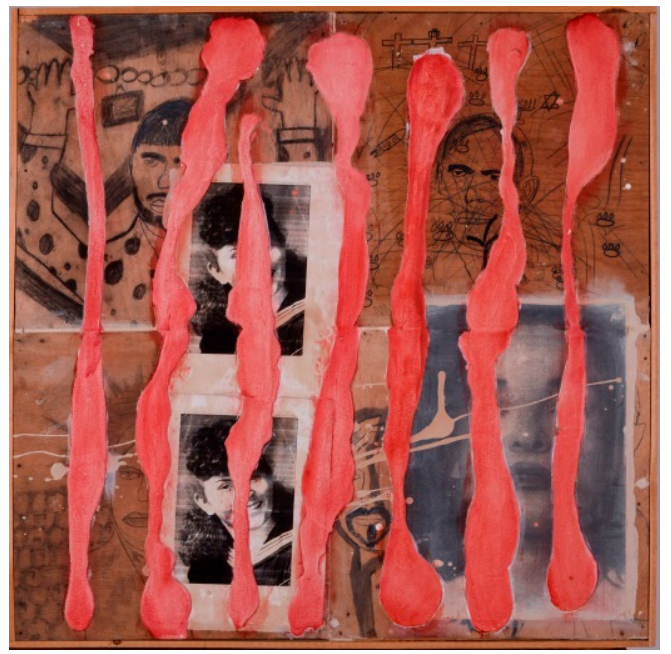

Figure 12. David Wakstein, Sonia, 2006, mixed media on plywood $81.5 \mathrm{~cm} \times 81.5 \mathrm{~cm}$. Image courtesy of the artist.

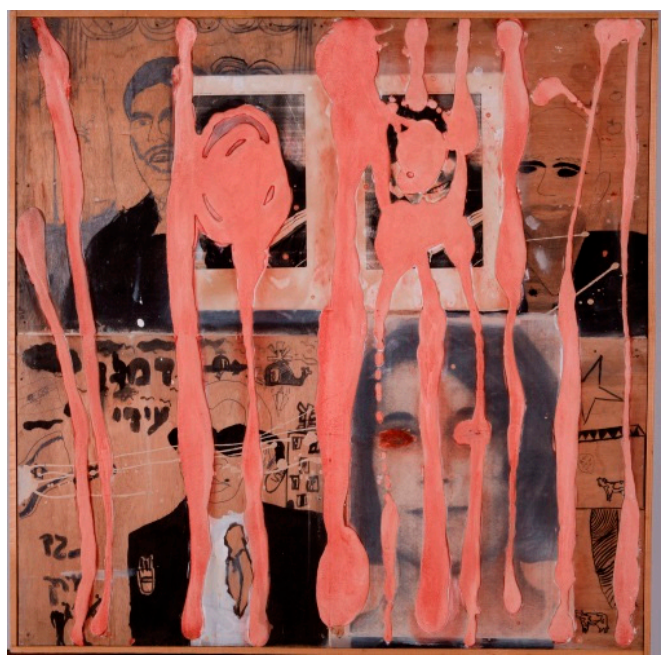

Figure 13. David Wakstein, Sonia, 2006, mixed media on plywood $81.5 \mathrm{~cm} \times 81.5 \mathrm{~cm}$. Image courtesy of the artist. 
Additional elements in these collages include childlike pencil drawings of a male figure, the Star of David (relating to both Jewishness and Israeliness), a photograph of another woman, ${ }^{24}$ and scattered words in Hebrew. Of special interest is the word "Salma" (סלמה) written in Hebrew on the upper-right-hand corner of Figure 10. The inclusion of the Hebrew letters forming what is a common Arab name associates the work with a local multicultural context-or rather with the tension between the two primary languages/populations in Israel. In fact, an important aspect of this series is that the artist created it based on studies that his young students made in a class devoted to drawing a male portrait. The students divided the plywood surface and drew the male figure and the symbols and words, and Wakstein added the photographs and the paint. He is known for his work with children from the periphery and for creating collaborative works with groups of Arab and Jewish children, a collaboration that plays a central role in generating these works' social meanings (Kessus Gedalyovich 2006). The artist notes that the name Salma in this work is a signature of one of his young students from the Joarish Quarter-a neighborhood populated primarily by Bedouin-Arab Muslims in the central Israeli city of Ramla. ${ }^{25}$

The inclusion of Salma's signature introduces an interaction between a Bedouin-Arab name (written in Hebrew and not in Arabic) and the strikingly Jewish European name Sonia (an Eastern European variant of the biblical name Sarah), which is both the central image and the title of this series. The inclusion of his student's signature within this very private recollection of his mother reflects an inclusive practice of collectively voicing multiple personal narratives and social identities. It demonstrates the multilayered complexity of Israel, past and present. Wakstein handles this complexity in an expressive, tense manner that blurs the boundaries between his own experience of traumatic immigration and loss and the children's apt expressions of identity stratification from the viewpoint of a member of the Bedouin minority in Israel.

\subsection{Haim Maor—Letste Nayes}

The historiography of Israeli art generally refers to Haim Maor (born in Israel, 1951) as an artist who focuses predominantly on Holocaust experiences, memory, and Jewish identity (Zalmona 2013, pp. 454-56; Liss 2014-2015, p. 61). Although this is true, it ignores his deep exploration into migratory identity, which deals with stratification on a much broader scale. Maor considers himself an outsider-both thematically and stylistically —in regard to the dominant local art scene (Romberg 2011, p. 248). Yet despite essential differences, certain aspects of his work relate to the artistic dictates described above that especially dominated the Midrasha School of Art where he studied. This is evident in Maor's use of a general structure of collage-inspired fragmentation, his frequent juxtaposition of text and image, and his use of wood at different stages of processing as the surface for his paintings. ${ }^{26}$ Moreover, in terms of color, it is possible to discern a nearly equal division in his artistic oeuvre between the use of vivid colors contributing to his realistic figuration and the choice of a limited palette confined to monochromatic beige, visually signifying past tense and enhancing notions of memory and loss.

In a triptych that Maor created in 2008, each panel consists of a painted silhouetted portrait mounted on a digital print of a newspaper spread in Yiddish (Figure 4). The title Self-Portrait with

24 Wakstein identified the other photograph as a portrait of Israeli curator Ruthi Director; it derives from another series dedicated to female curators on the Israeli art scene. The artist deliberately connects the image of these women with images of his mother in what he terms images of women who have influenced his life and are part of the constant blurring of boundaries in his art between his private life and the local art scene as artistic subject matter. As for the recurring male portrait, it is loosely based on a photograph of the former mayor of Rishon LeZion, where Wakstein lives; his students altered the image in one of Wakstein's studio lessons.

25 Ramla is mostly Jewish but also has a significant Arab minority of $25 \%$.

26 Wood not only serves as a surface in Maor's work, but is also a dominant feature in his art, which he sometimes emphasizes by using crude rather than treated wood. This is especially evident in a series executed over what bears the impression of a wooden fence: for example, in the works Pupil, 1995, industrial paint and lacquer on wood, $129 \mathrm{~cm} \times 81 \mathrm{~cm}$; Susanna-Shoshana, 1987, high-gloss paint and lacquer on wood, $70 \mathrm{~cm} \times 131 \mathrm{~cm}$. See the images in (Ofek 2011a, pp. 131-32). 
My Parents (Letste Nayes) identifies both the name of the newspaper and the figures he depicts. The ascription of Yiddish as the language spoken by Jews in Eastern Europe, from where his parents immigrated to Israel in 1949, might give the impression that in this case the representation rests solely on diasporic identity. Rather, Letste Nayes was a popular Yiddish newspaper printed in Israel between 1949 and 2006. The controversy around Yiddish is a central key to understanding this work. There were organized campaigns against the use of Yiddish among the new Jewish population in pre-state Israel during the 1920s and 1930s. After the establishment of the State in 1948, the use of Yiddish in local theater was officially banned because of its association with the diasporic Jew; again, at that time any other language was considered a threat to the creation of both a homogeneous Hebrew-speaking society and a cohesive nascent identity. ${ }^{27}$ The incorporated newspaper headlines-published in 1950-1951-were carefully chosen by Maor to touch upon the inseparability of national and personal histories. Yet, describing local events in Yiddish ironically defies their Israeliness, assuming the standpoint of a nonassimilated outsider. ${ }^{28}$

On the right, Maor attached his portrait to a caption celebrating two years from the foundation of the State of Israel, denoting his own birth a year later and thus reflecting his own status as part of the first generation of modern Jews who were born in an independent state. In contrast to the positive headline accompanying Maor's silhouette, he positioned his parents in a context of hardship. His father's portrait on the left is pasted on a cover page titled: "אונטער די חורבות פון יפו ליגט אונזער געוויסן! ("Under the Ruins in Jaffa Lies Our Conscience!"). This headline refers to a particular event in which a house in Jaffa was destroyed, resulting in the tragic deaths of a Jewish family. Maor's appropriation of these events into a current work might well evoke associations regarding the general significance of the history of Jaffa, a central Arab city whose population fled during the War of Independence in May 1948 and was officially annexed to Tel Aviv on April 1950 when this headline was published. Subsequently, Jewish newcomers repopulated Jaffa. Both Haim Maor and David Wakstein were born there, in Arab houses, a fact that both of them noted during our conversations. ${ }^{29}$ They also refer to these charged circumstances throughout their oeuvre as an integral part of their own identities. ${ }^{30}$

The central panel in Maor's triptych deals with a different painful confrontation: his mother's silhouette accompanies the headline "קאטאסטראפאלע לאגע אין די מעברות" ("A Catastrophic State in the Ma'abaroth"). During their first year in Israel, prior to their move to Jaffa, Maor's parents lived in a transit camp in Beer Ya'acov in central Israel, which was one of the temporary housing solutions for hundreds of thousands of newcomers during the massive immigration of 1948-1951. In one of our recent conversations, Maor noted that this headline has an additional hinted meaning triggered by the similarity of the sounds. ("camp"), which he associates with a concentration camp. One can understand Maor's intention in using the headline to evoke his parents' traumatic experiences as Holocaust survivors in the following

27 On the struggle between Yiddish and Hebrew during the first years of the State of Israel, see (Rojanski 2004); “The story of Yiddish in Israel is the story of the melting pot policy in miniature, a policy whose zealous implementers believed that immigrants from all the diasporas must relinquish-immediately and unhesitatingly — the cultures and traditions they had brought with them and adopt the local ethos and its culture. It was an unrealistic policy. In actuality the immigrants created cultural 'niches' that supplied their cultural desires and needs" (Shapira 2012, pp. 250-51).

28 "I was a child growing up in Israel during the 1950s. Yet, mentally, I was growing up in a 'bubble' of Warsaw. The language spoken in my home was Yiddish, and my parents spoke Polish between them." From a conversation with the artist, July 2019.

29 From conversations with the artists, May-July 2019.

30 Maor has often collaborated with Bedouin-Palestinian artist Khader Oshah, and Arab-Israeli artist Mohammad Said Kalash. Another interesting example is a Maor piece in which he wrote in Yiddish the words: " Arab"; untitled, 1989, $208 \mathrm{~cm} \times 152 \mathrm{~cm}$, collection of the artist). He embroidered this text on an ornamental satin curtain resembling the curtains covering the front of the Holy Ark in the synagogue. The result is an ironic obstruction of meaning and a hybridization of local identity that deals with religious Judaism, Yiddish, and Arab identity.

31 From a conversation with the artist, July 2019. 
remark: "My parents lived in a transit camp, and this was their last camp after worse camps." 32 This connection attests to their hardships but especially to their continual state of wandering.

A recent text by Maor titled Father's Suitcase reveals that, in fact, the newspaper pages he used for this work had belonged to his father:

"In 1949 I arrived in Israel with a single wooden suitcase".

I never saw it. After his passing I cleared the house. In a distant corner in the attic the lost suitcase was found. His name, David Moshkovitz, was written on one of its sides in blue ink, in the hesitant handwriting of a new immigrant. I opened it. It was filled with old Yiddish newspapers.

18 December 1951-“Letste Nayes: catastrophale lage in di ma'abarot" ("Latest News: Catastrophic Situation in the Transit Camps"). Fifty years later, the catastrophes and transit camps are still packed in his suitcase.

My father was a skilled wandering Jew: his possessions were always ready $[\ldots] .{ }^{33}$

Thus, the artist visually translates wandering-perceived as a cultural mindset-into a strikingly stereotypical representation of Jewish identity. Rather than referring to the land, a prime feature in the construction of the new Hebrew identity, this representation is in keeping with the perception of Jews as "people of the book" (עם הספר). Maor not only detaches these portraits from the background and from each other, while preserving an estranged diasporic language, but his use of a black silhouette creates a negative representation in which he outlines the figures in a way that denotes absence rather than presence. He underscores this impression by leaving the entire work devoid of color. In harnessing this visual language, which he intertwined with Yiddish, Maor incorporates his traumatic familial story into his own self-representation. He has recently elaborated on this notion by which his familial identity is imprinted on his sense of self:

My works do not spring ex nihilo. They do not begin with a blank white canvas, just as I, born in this country, was not born of the sea, nor did I romp on golden sands. From the moment I was born it was impressed upon me that I was a substitute, a continuation of members of the family killed in the extermination camp. I am supposed to perpetuate and memorialize them and the Jewish heritage of the Moshkowitzes from Plonsk and the Rutters from Lanzut, in Poland. This sensation filtered down into my artwork [ ... ]. ${ }^{34}$ (Maor 2014b, pp. 58-59)

\subsection{Neither Here nor There-Gary Goldstein's Ghosts}

In dealing with the history of families emigrating from Europe during the late 1940s, references to the Holocaust are inevitable. In a series that American-born Israeli artist Gary Goldstein (born 1950) created in 2005, he juxtaposes his family history of tragic loss with the celebration of Israel's first decade (Figures 2 and 14). He employs a similar collagistic arrangement of framed figures, separate from the background, to convey the same sense of irreconcilable identity fluctuating between homelands and cultures and the persistence of traumatic memory.

2 See (Ofek 2011b). They Are Me-Ruthi Ofek in Conversation with Haim Maor. In (Ofek 2011a, p. 290).

33 See (Maor). My Father's Suitcase. In (Ofek 2011a, p. 228).

34 This account refers to Maor's decision to Hebraize his family name of Moshkovits as a young adult and also relates to the fact that he bears his paternal grandfather's name. 


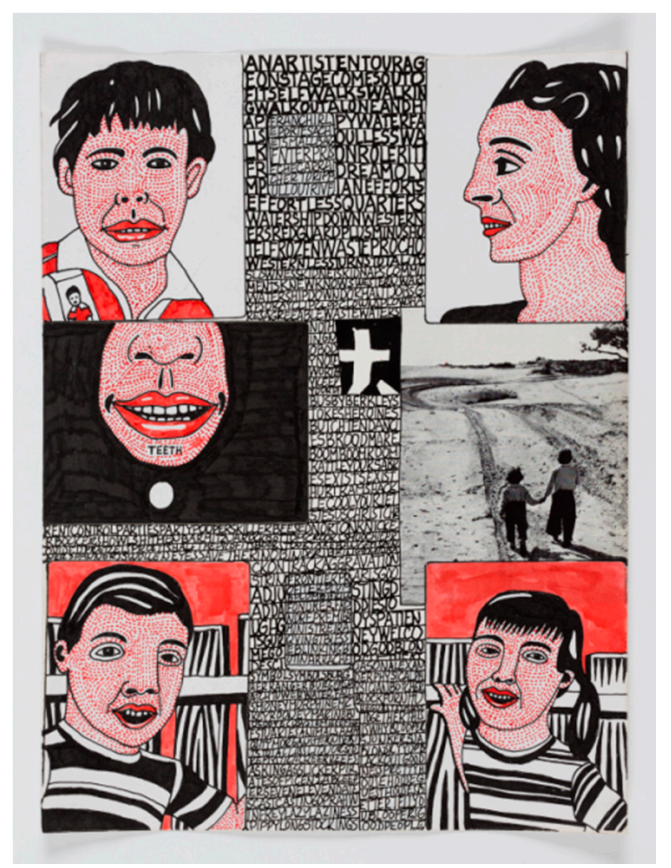

Figure 14. Gary Goldstein, from the series Israel's first decade, 2005, mixed media on paper, $29 \mathrm{~cm} \times 22$ $\mathrm{cm}$, The Levin Collection, Jerusalem. Image courtesy of Levin Art, Community \& Culture.

In contrast to Maor, however, Goldstein camouflages the identification of the figures in his work as members of his family. A son of Holocaust survivors, he was born in Nashville, Tennessee, raised in Hartford, Connecticut, in the 1950s, and immigrated alone to Israel in 1977. Although Goldstein differs from his colleagues discussed in this essay in his circumstances of immigration and was not raised in Israel, his works also deal with the Zionist mindset of a nascent collective identity and his sense of nonbelonging, a sense that was probably enhanced by his decision to live in a kibbutz during the first years of his arrival in Israel. His figures resemble images in American popular culture-from comic books to portraits published in Life Magazine - which left a deep impression on him as a child. ${ }^{35}$ Yet, a closer look reveals their frozen, distorted appearance, which evokes discomfort. In a recent text (soon to be published), Goldstein identifies these portraits:

I always knew that both my parents came from very large families. [ ... ] All those family members were murdered during the war. [ ... ] I never thought of their families, my families, and what happened to them. For me, their presence was one of lack. While preparing for a lecture at a conference at Bezalel, [ . . . ] I realized with surprise that my work assumed the guise of a forest of faces, a forest of portraits of people that I never met [ . . ] Yet, I never stop thinking about them. Their images appear, transform and reappear in drawing after drawing, year after year on pages of old books upon which I create my works. (Goldstein 2017)

Both examples shown here were taken from the same series, in which the work appears over the pages of a photo album that Israel published in 1958 to celebrate its first decade (Herman et al. 1958). Portraits of deceased diasporic family members hover over photographs emphasizing a deep connection to the land, one through which the new identity emerges.

Goldstein's use of English as a background in these works is especially interesting in terms of cultural identification. The seemingly accessible appearance of English, which cannot, in fact, be deciphered, turns a journal-like mode of exposure into a sequence of words with no spacing between them, triggered by associations that do not translate into a coherent text. What remains clear is the

35 From a conversation with the artist, July 2015. 
feeling that his works elicit an intimate account of the artists' personal world, which oscillates between exposure and concealment (Finkelstein 1999; Kraus 2010).

Covered by the dense handwriting in English, which further accentuates his foreign origins, this confrontation of the national celebration with a sense of nonbelonging is not meant as a criticism of the Zionist project itself. ${ }^{36}$ Rather, it reflects the persistence and omnipresence of diasporic consciousness and the incapability to fully belong. This blending of various cultural influences results in an overwhelming crowdedness, reflecting the artist's state of mind. In another recent text, he summarizes his sense of estranged identity:

Each sentence when I was growing up never ended in the same language in which it began. The English words were pronounced in a heavy, Yiddish accent something which made me ashamed. I looked down upon my parents, upon their foreignness. Those diminutives, Gersheleh, Hanka, Moisheleh, made them small. They made us small. They diminished us. They created the feeling in me of Gershon, a stranger in a strange land. Nicht a hier. Nicht a heir. Neither here nor there. (Goldstein 2017)

This childhood recollection of painful awareness of dissimilation emphasizes an important aspect that the works of Wakstein and Maor clearly articulate as well: constructing personal identity through utter rejection of their parents' identity.

A prominent recurring feature in the figures populating Goldstein's works is the awkwardness of their distorted mouths, colored in red and revealing their teeth. On the left side of Figure 14 a close-up of a cropped face focuses on the mouth, under which is the word "teeth". This is another indirect personal reference to his parents. The artist remembers their rotten teeth-a direct result of the terrible health conditions in the concentration camps during the war-in striking contrast to their relative youth. As he explains: "as Holocaust survivors in their 30s [ ... ] they were at the height of their beauty, and then, upon opening their mouths, they became grotesque. This mixture of attraction and repulsion [ ... ] appears in my work" (Goldstein 2015, p. 22). In Figure 14 the memory of these teeth hovers over a photograph of two young children walking toward the horizon in an arid local desert landscape filled with the promise of a new life.

\subsection{Philip Rantzer's Wandering Homes}

Philip Rantzer's studio display window in south Tel Aviv, which I mentioned at the beginning of this essay (Figures 1 and 2), serves as both a self-declaration of nonbelonging to the local culture and a statement that enhances diasporic origins. Despite his positive reception within the local art scene, Rantzer has always taken on the position of an outsider. Although his unique artistic practice corresponds primarily to international rather than local art (Ofek 2010, pp. 183-85; Guilat 2019b, p. 148), ${ }^{37}$ it still employs the same local aesthetic pattern delineated in this study. Although differing from the flat, two-dimensional collage works by Wakstein, Maor, and Goldstein in the way he implements this visual pattern in his art, Rantzer conveys a message that strongly relates to their work, as does the resulting notion of estrangement. He portrays this through the same aesthetic pattern, translating it into three-dimensions and creating complex assemblages that he develops into multimedia installations. His artistic language of excess might seem to contradict the meager essence that characterizes his colleagues' works and their local artistic genealogy. This excess is his principal artistic strategy: he uses it to focus on materiality and the strong associative meanings that the found objects he incorporates in his works bear. Hand-made miniature objects and scruffy ready-made used items, mostly from

36 The artist commented recently that he has never been cynical about the Zionist dream (Goldstein 2015, p. 21).

37 Rantzer's art is often referred to as Neo-Dada (Steinlauf 2002, p. 111). 
the domestic sphere or a junkyard, feature as if he discovered them in the family attic. ${ }^{38}$ Their rich sensual presence does not contradict, but rather conceals, the basic pattern he repeatedly employs in his work-one of framing, detaching, and compartmentalizing. Unlike his colleagues' figurative portrayals of their family members, he usually frames the domestic objects themselves, while strongly vivifying the presence of his parents through texts and the compelling impact of these domestic references and the atmosphere they evoke.

Two of Rantzer's installations, which he exhibited in the Israeli pavilion at the Venice Biennale of 1999, are quintessential examples of his intricate employment of migratory aesthetics (Figures 5 and 15-17). They both explicitly refer to his childhood memories marked by his emigration from Romania to Israel at the age of 4, in 1960. In a conversation with Aviad Kleinberg he clearly articulated the deep impact of this memory and the cultural demand to assimilate while shedding anything that could be perceived as diasporic:

As a child, having arrived from a neighborhood of immigrant transit camp evacuees to a neighborhood where we mixed with the local "salt of the earth", I was ridden by feelings of inferiority. I looked for a way to be an equal among equals. I couldn't be equal the Sabra way. [ ... ] I took the Diaspora way (the Jewish way): using humor, becoming the classroom artist. (Kleinberg 2010, p. 170)

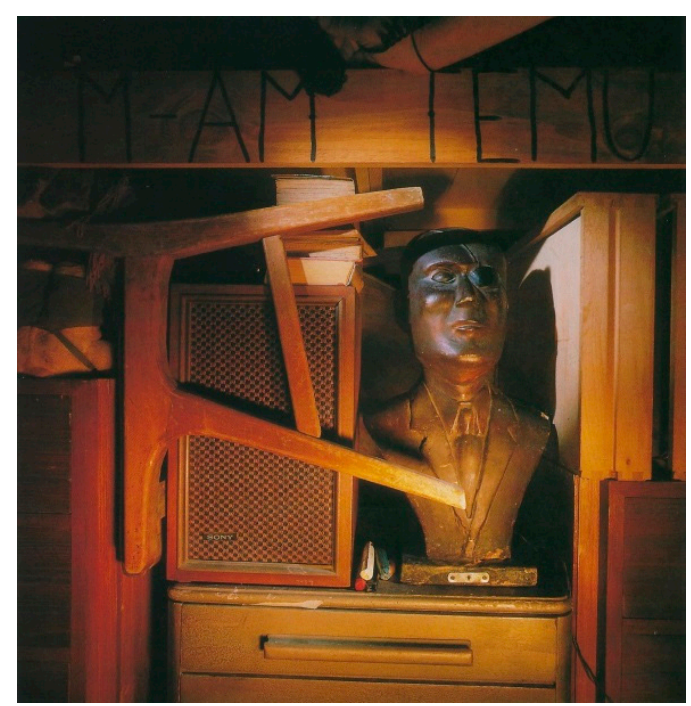

Figure 15. Philip Rantzer, Untitled, 1999. Details from an installation at the Venice Biennale, 1999. Photograph: Philip Rantzer. Image courtesy of the artist.

38 The result bears a strong resemblance to Robert Rauschenberg's assemblages (termed "combines") of the 1950s, in dealing with childhood memories through the inclusion of ready-made objects in his work. On this aspect of Rauschenberg's early works, see (Branden 2003, pp. 141-44). For a similar interpretation, see (Cage 1961, p. 103). 


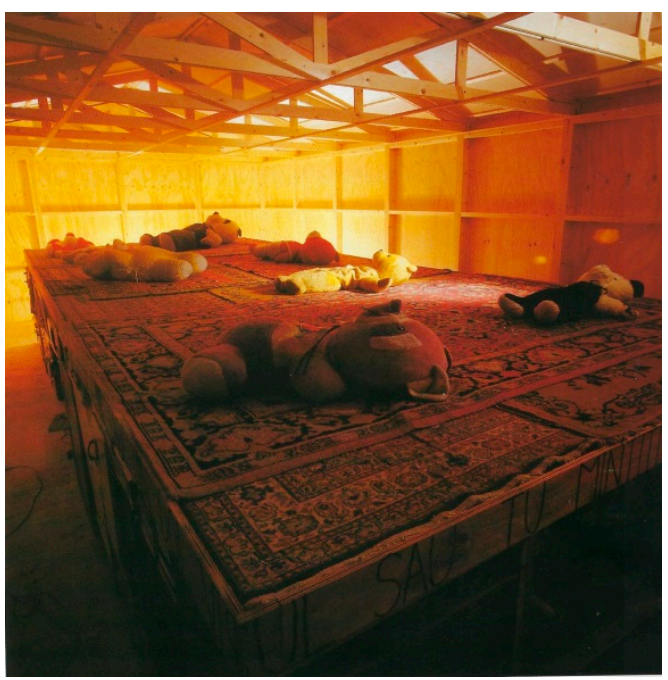

Figure 16. Philip Rantzer, Untitled, 1999. Details from an installation at the Venice Biennale, 1999. Photograph: Philip Rantzer. Image courtesy of the artist.

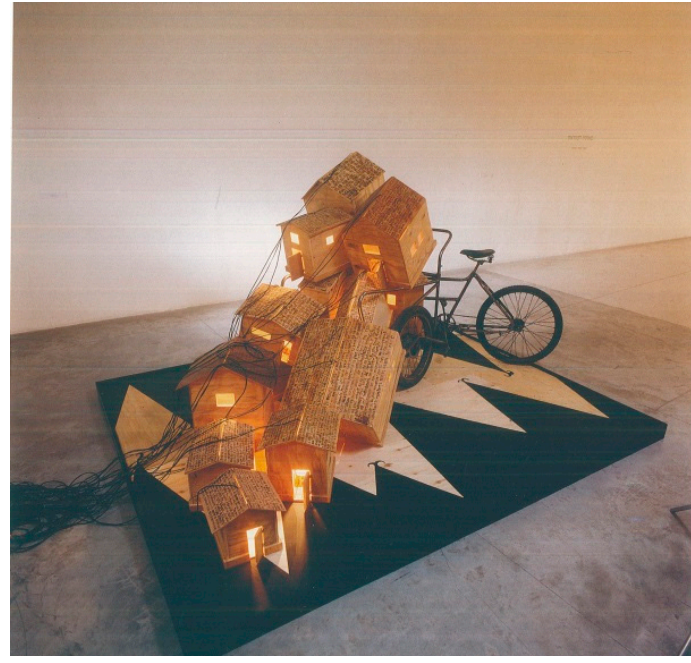

(a)

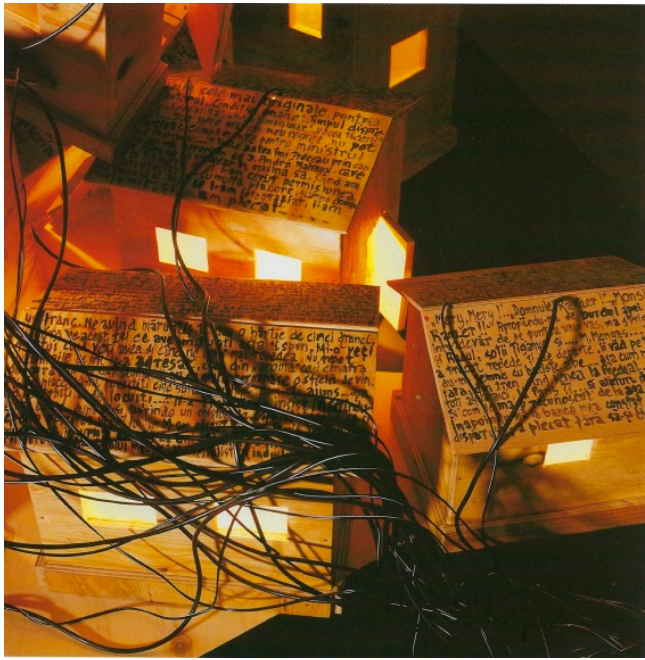

(b)

Figure 17. (a) Philip Rantzer, The Day Daddy Met Mommy, 1999, wooden houses, three-wheeled cart, sound, dimensions variable, The Israel Museum, Jerusalem, Gift of Dov and Rachel Gottesman Fund, Tel Aviv and Geneva B00.1113. Image courtesy of the artist. (b) Enlarged detail, image courtesy of the artist.

The first installation is a large wooden shack $(10 \times 5 \times 2$ square meters). In the center of the room within it, Rantzer constructed a high platform from various fragments of furniture that he arranged into a dense rectangular shape. ${ }^{39}$ Taking up most of the space, this platform was $8 \mathrm{~m}$ long, its height reaching $1.2 \mathrm{~m}$. The organization of its components into small sections creates a compartmentalization with the general appearance of a living-room cupboard. The artist scattered several photographs, small busts, and dolls, enclosing them within the wooden sections, books, and drawers (Figures 5 and 15). One of the busts (Figure 5) is evidently of the Zionist leader Theodor Herzl (1860-1904), known as the visionary of the State. By implanting his bust in this hybrid domestic environment, Rantzer contextualizes this experience of uprooting within the Zionist narrative. More specifically,

39 Rantzer has described this work as "a kind of a hybrid stage comprised of fragmented furniture". From a conversation with the artist, July 2019. 
juxtaposing Herzl's bust with the framed childhood dolls—which he placed right above it-raises questions regarding the realization of the Zionist dream and the personal price that immigrants pay for it.

Rantzer covered the top of this platform with old tattered carpets on which he laid large teddy bears (Figure 16). A loud looped audio recording of a baby crying triggered by the movement of the viewers in the crowded shack accompanied the work (Aharonson 1999a). ${ }^{40}$ The artist's intention was to create a claustrophobic atmosphere that lured the spectator into a dream-like daunting distant memory of a child. His own childhood experience of immigration is translated into a surrealistic hybridization and fragmentation, destabilizing the notion of the home in an unsettling environment of uprooting, displacement, and loss. The most effective, extraordinary aspect of this work is that it was designed to create a distorted perspective-conveying the imaged experience through the eyes of a child. Accordingly, the high platform was meant to adjust the adult spectators' viewpoint to the lower perspective of a small child, as suggested by the large sizes of the teddy bears. A detail that further connects this work with the artist's personal narrative is a strip of text showing the lyrics of a popular Romanian song (Figure 5). When Rantzer was a child his father used to sing this poetic love song—about a man who dreams that his beloved leaves him—as a lullaby. ${ }^{41}$

In the second installation, the appearance of a written text in Romanian becomes much more dominant, identifying the depicted home as the diasporic one more explicitly (Figure 17a). It is made up of a dozen hand-made boxes in the shapes of miniature houses that have spilled out of the top of a bicycle. The roofs are covered with a meticulously handwritten text in Romanian, repeatedly telling the story of Rantzer's parents' first meeting. For most viewers, unfamiliar with Romanian, this signifies foreignness while intentionally withholding its full meaning. The story, as frequently told by Rantzer's father, ${ }^{42}$ was actually written on these roofs by the father himself. This fact, unknown to the audience, creates a unique incorporation of presence versus memory and absence in the work. As in his wooden shack, the work adopts a child's worldview, as explicitly stated in the title: The Day Daddy Met Mommy. Using the words "daddy" and "mommy" — as a child would say them-makes it clear once again that the work relates to the artist's childhood memories. He also expresses this through the miniature houses that look like doll houses, lit by lightbulbs and containing miniature pieces of furniture or figures. The electric wiring connects the collapsing houses, which seem caught in a frozen moment of descent; this is a droll positioning that creates an ironic hybridity between a state of motion and wandering and one of stability, which Rantzer's work undermines in a disturbing way.

Whereas these representations of identity have negotiated the unsolved alternation between belonging and nonbelonging through their juxtaposition, Rantzer seems especially determined to place himself in the nonbelonging camp. Although he has lived in Israel for most of his life, he describes his home in his works as the diasporic one and Romanian as his language. Two of his comments reflect a state of dissociation. Rather than feeling Israeli, he defines himself primarily as Jewish:

I still feel like an immigrant. I am an old-newcomer, but still a newcomer. An old immigrant [ ... ] I still speak Romanian with my parents. This is the language I grew up with. Somehow I feel intimacy precisely with that which is remote. [ ... ] I feel Jewish in an almost stereotypical sense. (Kleinberg 2010, p. 170)

[ ... my art] expresses a type of dissociation, detachment. Israeliness is comprised of this detachment, and mainly of not knowing. Israeliness is to be a conqueror and a defeatist, hero and dodger, to be all these things simultaneously. It's the crystallization of a new and

40 In a Closed Space. In (Aharonson 1999c, p. 148).

41 The words "minchunile din vis" ("the lies of the dream"), which Rantzer quoted from this song, reappear in another multimedia installation that he created in 2006 under the title 10E, consisting of a car, a video, and sound. See the image in (Ofek and Yariv 2010, pp. 140-41).

42 It is a romantic and lively account of the first moment he saw her, and his immediate realization, while conversing with a friend on the street, was that she would become his wife. 
reformed place, which consists of these antithetical components. In the meantime, everything here is constantly crystallizing. In relation to this, Judaism is eternity. It is something so ancient and elementary-perhaps it is my anchor. ${ }^{43}$ (Aharonson 1999b, p. 158)

The notion of nonbelonging as inherent to a Jewish frame of mind in contradiction to an assimilated, stable, sense of self-as highlighted in Rantzer's works and certainly in Maor's and Goldstein's art as well-is not a new one. In the context of artistic practice, it is especially evident in Jewish American artist R. B. Kitaj's (1932-2007) well-known First Diasporist Manifesto (Kitaj 1989). First published in 1989, it might well have been a direct source of influence on Rantzer and his colleagues, echoing their own personal experiences. Kitaj's manifesto captures the same essence of Jewishness as an inner state of wandering, of being uprooted, living "in two or more cultures at once"44 (ibid., p. 19).

\subsection{A Concluding Discussion}

The binary pattern delineated in the present study is governed by dialectic juxtapositions. Wakstein, Maor, Goldstein, and Rantzer employ visual strategies of framing, detaching, and fragmenting to express the cultural phenomenon of identity hybridization. Recollection of childhood memories that are confronted from a vantage point of maturity are sublimated and projected onto these visual schemes. The choice to make use of a very appropriate collagistic pattern and the meager local style prevalent during the 1970s, the time when they all emerged as artists, is twofold. First and foremost, it is a strategy for conveying the dialectic dualism lying at the core of their experiences of immigration. Second, through this belated revival of the predominant artistic style - considered as quintessentially Israeli-these artists subvert what it stands for, replacing it with both a hybrid selfhood and a clear demand to reclaim their diasporic roots in order to reframe a self-articulation that can, in the perspective of time, accommodate its inherent multicultural complexity.

The analyses of the artworks under discussion (Figures 2-5) indicates that these works serve as visual metaphors for the dichotomy of two local identity models represented by the artists' parents on the one hand and their own new "Sabra" self-determination on the other. This particular migratory aesthetic supplies a deeply fitting visualization of a local identity clash, forcefully experienced by this first generation of new Jewish-Israelis. The early 1950s marked the formative years of the young State of Israel, characterized and influenced by the Zionist ethos. A massive wave of immigration dominated the period, but the Israelis already resident in the country utterly rejected the immigrants' diverse cultural backgrounds (the "melting pot" policy). Consequently, the 1950s generation embodies the clash between "here" and "there". These national cultural dictates meant that in order to become Israeli, members of this generation had to reject their parents' roots, history, mentality, and language. Their artworks directly confront this tremendous tension, vacillating between unreconciled binaries.

Another common denominator among all four of these artists is the use of text as a counterbalance to the framed figures in their works. The predominance of text is another notable characteristic of local art (Bolas 1996), varying from newspaper articles to love song lyrics, and personal diary-like texts covering the whole background (Goldstein and Maor) or simply inserting a word or a sentence that adds hidden layers of meaning (Rantzer and Wakstein). Most significantly, these artists affirm the hybrid nature of an immigrants' country through the use of different languages. As most audiences are unfamiliar with Yiddish and especially with Romanian, the status of these languages as foreign becomes a message in itself, representing both an obstacle to conversation or comprehension and an affinity to diasporic roots. This is also true in the case of Goldstein, who ironically employs the common language of English in an illegible way. We see a different use of text in one of Wakstein's

43 A Jewish Peter Pan, in (Aharonson 1999c, p. 158).

44 "Painting is a great idea I carry from place to place. It is an idea full of ideas, like a refugee's suitcase, a portable Ark of the Covenant" (ibid., p. 11). As noted above, on the significance of the notion of wandering in Jewish thought and in shaping Israeli self-articulation, see also (Shapira 1991) 
works in the inclusion of the signature of one of his Arab-Bedouin students "Salma", which reflects another dimension in social stratification as it borrows the young woman's identity. The presence of Arab identity as an integral part of local identity appears obliquely in Maor's triptych as well.

These works not only undermine the possibility of consolidating a cohesive local identity, but further they deem it irrelevant. This occurs at the particular crossroads of local and global developments within the cultural discourse and reflects a new attitude toward migration as a continuing emotional and cultural mindset. Through a highly personalized point of view, these artworks articulate an inability to fully belong. The autobiographical narrative challenges the meta-narrative of the Zionist ethos. The result is a nomadic essence of being neither "here" nor "there". It is precisely because of these unique circumstances that the Israeli case constitutes an important manifestation of migratory aesthetics, transcending the local and showing the experience of migration as a contemporary worldwide state of mind. Some of these artists do not feel fully Israeli, and prefer to define themselves as "old-newcomers", an ironic assertion that encapsulates an uncanny sense of self. By reclaiming the identity of the diasporic Jew, they rebuff the dichotomy at the core of Zionism between being Israeli and being Jewish. Rather, taken positively, the Jewish notion of wandering is a frame of mind that is in an interesting alliance with the current notion of the mobility turn.

There is room for further study of the particularities of local migratory aesthetics. The analysis presented here is part of wider ongoing study that explores different visual strategies of coping with migration and (non)belonging that we find in the particular circumstances that inform Israeli identity. Whether such patterns apply or will apply to the works of other generations of artists-and especially whether additional patterns will become apparent in addressing certain minority groups in the current local society—remains to be seen.

Funding: This research received no external funding.

Acknowledgments: I would like to thank Prof. Haim Finkelstein for insightful reading and remarks on an earlier version of this text. An early, short version of this research, titled "Immigration, Estrangement and (Un)belonging in Israeli Art", was presented at the 35th Annual Conference of the Association for Israel Studies, Kinneret College, June 2019.

Conflicts of Interest: The author declares no conflicts of interest.

\section{References}

Aharonson, Meir, ed. 1999a. In a Closed Space. In Memory as History, History as Memory—Philip Rantzer, Simcha Shirman. The Venice Biennale, Israeli Pavilion Exhibition Catalog. Tel Aviv: Ministry of Education, pp. 145-48.

Aharonson, Meir, ed. 1999b. A Jewish Peter Pan. In Memory as History, History as Memory-Philip Rantzer, Simcha Shirman. The Venice Biennale, Israeli Pavilion Exhibition Catalog. Tel Aviv: Ministry of Education, pp. 158-60.

Aharonson, Meir, ed. 1999c. Memory as History, History as Memory-Philip Rantzer, Simcha Shirman. The Venice Biennale, Israeli Pavilion Exhibition Catalog. Tel Aviv: Ministry of Education.

Ankori, Gannit. 2006. Palestinian Art. London: Reaktion.

Bal, Mieke. 2007. Lost in Space, Lost in the Library. In Essays in Migratory Aesthetics: Cultural Practices between Migration and Art-Making. Edited by Sam Durrant and Catherine M. Lord. Thamyris/Intersecting: Place, Sex and Race. Amsterdam: Rodopi B.V., vol. 17, pp. 23-36.

Barkai, Sigal. 2016. 'Historiographic Irony': On Art, Nationality and In-Between Identities. Studies in Visual Arts and Communication 3: 1-12.

Barthes, Roland. 1981. Camera Lucida: Reflections on Photography. Translated by Richard Howard. New York: Hill and Wang.

Bolas, Gerald D., ed. 1996. Ketav, Flesh and Word in Israeli Art. Exhibition Catalog. Chapel Hill: Ackland Art Museum.

Bourdieu, Pierre. 1991. Language and Symbolic Power. Translated by Gino Raymond, and Matthew Adamson. Cambridge: Harvard University Press.

Branden, Joseph W. 2003. Random Order-Robert Rauschenberg and the Neo-Avant-Garde. Cambridge: MIT Press. 
Breitberg-Semel, Sarah, ed. 1986. The Want of Matter as Quality in Israeli Art. Exhibition catalog. Tel-Aviv: Tel Aviv Museum of Art.

Breitberg-Semel, Sarah, ed. 2011a. Gershuni-Selected Translations from the Hebrew Edition. Exhibition catalog. Tel Aviv: Tel Aviv Museum of Art.

Breitberg-Semel, Sarah, ed. 2011b. Radicalism with a Fold: The First half of the 1970s. In Gershuni. Exhibition Catalog. Tel Aviv: Tel Aviv Museum of Art, pp. 52-69. (In Hebrew)

Cage, John. 1961. Silence. Middletown: Wesleyan University Press.

De Souza, Pauline. 2011. Implications of Blackness in Contemporary Art. In A Companion to Contemporary Art since 1945. Edited by Amelia Jones. Malden: Blackwell Press, pp. 356-77.

Dekel, Tal. 2016. Transnational Identities-Women, Art and Migration in Contemporary Israel. Detroit: Wayne State University Press.

Dekel, Tal, Efrat Yerday, Esti Almo Wexler, and Shula Keshet (Kashi), eds. 2017. The Monk and the Lion: Contemporary Ethiopian Visual Art in Israel. Gila Svirsky, trans. Tel Aviv: Ahoti-for Women in Israel.

Durrant, Sam, and Catherine M. Lord, eds. 2007a. Essays in Migratory Aesthetics: Cultural Practices between Migration and Art-Making. Thamyris/Intersecting: Place, Sex and Race. Amsterdam: Rodopi B.V., vol. 17.

Durrant, Sam, and Catherine M. Lord. 2007b. Introduction. In Essays in Migratory Aesthetics: Cultural Practices between Migration and Art-Making. Thamyris/Intersecting: Place, Sex and Race. Amsterdam: Rodopi B.V., vol. 17, pp. 11-20.

Edelsztein, Sergio. 1993. Choreographer of Junk—Sergio Edelsztein and Philip Rantzer, a conversation. In Philip Rantzer. Edited by Sergio Edelsztein. Exhibition Catalog. Tel Aviv: Artifact Gallery, pp. 52-58.

Finkelstein, Haim. 1999. Gary Goldstein: Cyclical/Recycled. Exhibition Catalog. Beer Sheva: Avraham Baron Art Gallery, Ben Gurion University of the Negev, pages unnumbered.

Fischer, Yona, and Tamar Manor-Fridman, eds. 2008. The Birth of Now: Art in Israel in the 1960s. Anat Schultz, trans. Exhibition Catalog. Ashdod: Ashdod Museum of Art.

Goldscheider, Calvin. 2016. Immigration: Social Strains and the Challenge of Diversity. In Contemporary Israel, New Insights and Scholarship. Edited by Frederick E. Greenspahn. Jewish Studies in the Twenty-First Century. New York: New York University Press, pp. 65-84.

Goldstein, Gary. 2015. Searching for a Homeland among the Leaves of Old Books. In Israel: Land and Identity-Artworks from the Levin Collection, Jerusalem. Edited by Emma Gashinsky. Exhibition Catalog. Vienna and Jerusalem: The Levin Foundation, pp. 21-24.

Goldstein, Gary. 2017. Extract from an unpublished text. Unpublished work.

Greenberg, Clement. 1959. Collage. In Art and Culture_Critical Essays. Edited by Clement Greenberg. New York: Beacon Press, pp. 71-83.

Guilat, Yael. 2019a. 'Living Room' and 'Family Gaze' in Contemporary Israeli Art: Comparative Perspectives on Cultural-Identity Representations. Israel Studies 24: 24-53. [CrossRef]

Guilat, Yael. 2019b. The 'Lost' Generation: Young Artists in 1980s Israeli Art. Sede Boker: The Ben-Gurion Research Institute. (In Hebrew)

Hadar, Irith. 2009. Connections and Attributions. In Mind the Cracks!-Collages from the Museum and from Other Collections. Edited by Irith Hadar. Exhibition Catalog. Tel Aviv: Tel Aviv Museum of Art, pp. 169-72.

Herman, Avraham, Yigal Yadin, and Amir Gilboa. 1958. Israel's First Decade. Tel Aviv: Masada.

Kessus Gedalyovich, Michael, ed. 2006. Liberty: David Wakstein + Art Team. Tel Aviv: Omanut La'am. (In Hebrew) Kitaj, Ronald Brooks. 1989. First Diasporist Manifesto. London: Thames \& Hudson.

Kleinberg, Aviad. 2010. Look Back in Anger-Aviad Kleinberg in Conversation with Philip Rantzer. In Philip Ranzter-Look Back in Anger. Edited by Ruti Ofek and Amon Yariv. Exhibition Catalog. Tel Aviv: The Open Museum, Tefen Industrial Park and Gordon Gallery, pp. 161-74.

Kraus, Ora. 2010. Preface. In Down to the Smallest Details. Edited by Ora Kraus. Exhibition Catalog. Rehovot: Rehovot Municipal Gallery.

Liss, Dvora, ed. 2014-2015. Good Jew. Exhibition Catalog. Ein Harod: Mishkan Museum of Art.

Makhoul, Bashir, and Gordon Hon. 2013. The Origins of Palestinian Art. Liverpool: Liverpool University Press.

Maor, Haim. My Father's Suitcase. In Haim Maor-They Are Me. Edited by Ruthi Ofek. Exhibition Catalog. Tefen: The Open Museum and Omer Industrial Parks, p. 228.

Maor, Haim, ed. 2014a. Broken Beads—Contemporary Artists on their Moroccan Identity. Exhibition Catalog. Be'er Sheva: Senate Gallery, Ben-Gurion University of the Negev. 
Maor, Haim. 2014b. A Good Jew-Twice as Good. In Good Jew. Edited by Dvora Liss. Exhibition Catalog. Ein Harod: Mishkan Museum of Art, pp. 51-59.

Mathur, Saloni, ed. 2011. The Migrant's Time: Rethinking Art History and Diaspora. Williamstown: Sterling and Francine Clark Art Institute.

Mitchel, William J. T. 2011. Migration, Law, and the Image: Beyond the Veil of Ignorance. In The Migrant's Time: Rethinking Art History and Diaspora. Edited by Mathur Saloni. Williamstown: Sterling and Francine Clark Art Institute, pp. 59-77.

Ofek, Ruthi. 2010. A calculated Game. In Philip Rantzer—Look Back in Anger. Edited by Ruthi Ofek and Amon Yariv. Exhibition Catalog. Tel Aviv: The Open Museum, Tefen Industrial Park and Gordon Gallery.

Ofek, Ruthi. 2011a. Haim Maor-They Are Me. Edited by Ruthi Ofek. Exhibition Catalog. Tefen: The Open Museum and Omer Industrial Parks.

Ofek, Ruthi. 2011b. They are Me-Ruthi Ofek in Conversation with Haim Maor. In Haim Maor-They Are Me. Edited by Ruthi Ofek. Exhibition Catalog. Tefen: The Open Museum and Omer Industrial Parks, pp. 280-94.

Ofek, Ruthi, and Amon Yariv, eds. 2010. Philip Ranzter_Look Back in Anger. Exhibition Catalog. Tel Aviv: The Open Museum, Tefen Industrial Park and Gordon Gallery.

Ofrat, Gideon. 1980. The New Jerusalem School. In The Story of Israeli Art. Edited by Binyamin Tamuz. Tel Aviv: Masada, pp. 277-327. (In Hebrew)

Ofrat, Gideon. 1998. One Hundred Years of Art in Israel. Translated by Peretz Kidron. Boulder: Westview Press in Cooperation with the Mizel Museum of Judaica.

Ofrat, Gideon. 2013. Broader Horizons-120 Years of Israeli Art, from the Ofrat Collection to the Levin Collection, Selected Works, Part II. Tel-Aviv: Vienna-Jerusalem Foundation for Israeli Art.

Petersen, Anne Ring. 2017. Migration into Art; Transcultural Identities and Art-making in a Globalised World. Manchester: Manchester University Press.

Raz-Krakotzkin, Amnon. 2017. Exile within Sovereignty: Critique of "The Negation of Exile" in Israeli Culture. In The Scaffolding of Sovereignty. Edited by Zvi Ben-Dor Benite, Stefanos Geroulanos and Nicole Jerr. New York: Columbia University Press, pp. 393-420.

Rojanski, Rachel. 2004. The Status of Yiddish in Israel, 1948-1951: An Overview. In Yiddish after the Holocaust. Edited by Joseph Sherman. Syracuse: Boulevard Books, pp. 46-59.

Romberg, Osvaldo. 2011. Haim Maor: A Lone Rider. In Haim Maor-They are Me. Edited by Ruthi Ofek. Exhibition Catalog. Tefen: The Open Museum, Tefen and Omer Industrial Parks, pp. 247-48.

Shapira, Sarit. 1991. Landmarks: A Local Development. In Routes of Wandering: Nomadism, Journeys and Transitions in Contemporary Israeli Art. Edited by Sarit Shapira. Translated by Richard Flantz. Exhibition Catalog. Jerusalem: The Israel Museum, pp. 48-65.

Shapira, Anita. 2012. Israel-A History. Translated by Anthony Berris. Waltham: Brandeis University Press.

Shapira, Yaniv, ed. 2014. David Wakstein Painting, 1975-2014. Exhibition Catalog. Ein Harod: Mishkan Museum of Art.

Shehori, Ran. 1974. Art in Israel. Tel Aviv: Sadan.

Silvain, Gerard, and Henri Minczeles. 1999. Yiddishland. Translated by David Wharry. English Edition Edited by Donna Wiemann. Corte Madera: Gingko Press.

Steinlauf, Varda. 2002. Neverending Story. In Philip Rantzer-No No No Don't Leave Me Alone Here. Edited by Varda Steinlauf. Exhibition Catalog. Tel Aviv: Tel Aviv Museum of Art, pp. 103-12.

Urry, John. 2007. Mobilities. Cambridge: Polity Press.

Zalmona, Yigal. 2013. 100 Years of Israeli Art. Farnham: Lund Humphries in Association with the Israel Museum, Jerusalem.

Zalmona, Yigal, and Tamar Manor-Friedman, eds. 1998. Kadima-The East in Israeli Art. Exhibition Catalog. Jerusalem: The Israel Museum.

Zuckermann, Moshe. 2015. Aspects of the Negation of Diaspora. In Israeli Exiles: Homeland and Exile in Israeli Discourse. Edited by Ofer Shiff. Iyunim Bitkumat Israel: Thematic Series Vol. 10; Be'er Sheva: Ben-Gurion Research Institute for the Study of Israel and Zionism, Ben-Gurion University of the Negev, pp. vii, 232-39.

(C) 2019 by the author. Licensee MDPI, Basel, Switzerland. This article is an open access article distributed under the terms and conditions of the Creative Commons Attribution (CC BY) license (http://creativecommons.org/licenses/by/4.0/). 